OPEN ACCESS

Edited by:

II-Nam Kim,

Incheon National University,

South Korea

Reviewed by:

Ju-Hyoung Kim,

Kunsan National University,

South Korea

Margarita Fernández Tejedor, Institute of Agrifood Research and Technology (IRTA), Spain

*Correspondence:

Marius N. Müller

mariusnmuller@gmail.com

Specialty section

This article was submitted to

Marine Biogeochemistry,

a section of the journal

Frontiers in Marine Science

Received: 22 October 2018

Accepted: 13 February 2019

Published: 26 February 2019

Citation:

Müller MN, Dorantes-Aranda J J, Seger A, Botana MT, Brandini FP and Hallegraeff GM (2019) Ichthyotoxicity of the Dinoflagellate Karlodinium

veneficum in Response to Changes in Seawater pH. Front. Mar. Sci. 6:82. doi: 10.3389/fmars.2019.00082

\section{Ichthyotoxicity of the Dinoflagellate Karlodinium veneficum in Response to Changes in Seawater pH}

\author{
Marius N. Müller ${ }^{1 *}$, Juan José Dorantes-Aranda ${ }^{2}$, Andreas Seger ${ }^{2}$, Marina T. Botana $^{3}$, \\ Frederico P. Brandini ${ }^{3}$ and Gustaaf M. Hallegraeff ${ }^{2}$
}

${ }^{1}$ Department of Oceanography, Federal University of Pernambuco, Recife, Brazil, ${ }^{2}$ Institute for Marine and Antarctic Studies, Hobart, TAS, Australia, ${ }^{3}$ Oceanographic Institute, University of São Paulo, São Paulo, Brazil

The ichthyotoxic dinoflagellate Karlodinium veneficum has a worldwide distribution and produces highly potent lytic toxins (karlotoxins) that have been associated with massive fish kill events in coastal environments. The capacity of $K$. veneficum to gain energy from photosynthesis as well as phagotrophy enables cellular maintenance, growth and dispersal under a broad range of environmental conditions. Coastal ecosystems are highly dynamic in light of the prevailing physicochemical conditions, such as seawater carbonate speciation $\left(\mathrm{CO}_{2}, \mathrm{HCO}_{3}{ }^{-}\right.$, and $\left.\mathrm{CO}_{3}{ }^{2-}\right)$ and $\mathrm{pH}$. Here, we monitored the growth rate and ichthyotoxicity of $K$. veneficum in response to a seawater $\mathrm{pH}$ gradient. $\mathrm{K}$. veneficum exhibited a significant linear reduction in growth rate with elevated seawater acidity $\left[\mathrm{pH}_{\text {(totalscale) }}\right.$ from 8.05 to 7.50$]$. Ichthyotoxicity was assessed by exposing fish gill cells to $K$. veneficum extracts and subsequent quantification of gill cell viability via resorufin fluorescence. Extracts of $K$. veneficum indicated increased toxicity when derived from elevated $\mathrm{pH}$ treatments. The variation in growth rate and toxin production per cell in regard to seawater $\mathrm{pH}$ implies that (1) future alteration of seawater carbonate speciation, due to anthropogenic ocean acidification, may negatively influence physiological performance and ecosystem interactions of $K$. veneficum and (2) elevated seawater $\mathrm{pH}$ values (> 8.0) represent favorable conditions for $K$. veneficum growth and toxicity. This suggests that prey of $K$. veneficum may be exposed to increased karlotoxin concentrations at conditions when nutrients are scarce and seawater $\mathrm{pH}$ has been elevated due to high photosynthetic activity from prior autotrophic phytoplankton blooms.

Keywords: Harmful dinoflagellate, ocean acidification, seawater carbonate chemistry, toxin production, Karlodinium veneficum, ichthyotoxicity

\section{INTRODUCTION}

The accumulation of anthropogenic carbon dioxide in the atmosphere and its concomitant absorption by the ocean surface causes distinct chemical changes, known as ocean acidification (reduction of $\mathrm{pH}$ and increase of $\mathrm{CO}_{2}$ ). Ocean acidification has been recorded over the past decades at long-term monitoring stations (Dore et al., 2009) and has the potential to affect phytoplankton physiology and community structure (Dutkiewicz et al., 2015). In comparison to the open ocean, 
coastal areas are subject to multiple environmental drivers, such as riverine fresh water input, eutrophication, aquaculture fish farming, deep-water upwelling and high biological productivity. These factors result in highly fluctuating $\mathrm{pH}$ regimes with seasonal and daily changes of up to $0.6 \mathrm{pH}$ units (Duarte et al., 2013; Melzner et al., 2013; Carstensen et al., 2018). For example, upwelling waters with $\mathrm{pH}$ values $<7.7$ have been reported for the continental shelfs of California and Chile (Feely et al., 2008; Torres et al., 2011). Less buffered waters of marine aquaculture facilities can even reach acidic $\mathrm{pH}$ levels corresponding to $\mathrm{pCO}_{2}$ values $>10,000 \mu \mathrm{atm}$, associated with high respiration rates and organismal densities (Ellis et al., 2017).

The marine dinoflagellate Karlodinium veneficum has a global distribution and produces powerful lytic karlotoxins that have been associated with extensive fish kills (Mooney et al., 2010; Place et al., 2012; Adolf et al., 2015; EscobarMorales and Hernández-Becerril, 2015). Emerging evidence suggests that these toxins are primarily produced to facilitate feeding by prey immobilization (Sheng et al., 2010). Strain specific variability of $K$. veneficum has been demonstrated in regard to trophic growth mode (auto- and mixotrophy), toxin production and DNA content which suggests the existence of different ecotypes (Place et al., 2012). Nutrient availability and other environmental drivers, such as seawater carbonate chemistry, have the potential to alter growth and cellular toxicity of $K$. veneficum (Fu et al., 2010). Here, we present controlled laboratory experiments investigating the autotrophic growth and ichthyotoxicity of one $K$. veneficum strain in response to an extended seawater $\mathrm{pH}$ gradient.

\section{MATERIALS AND METHODS}

\section{Culture Conditions}

Monospecific cultures of K. veneficum (strain KVSR01, obtained from the Algae Culture Collection at the Institute for Marine and Antarctic Studies of the University of Tasmania, Australia) were maintained in filter-sterilized $(0.2 \mu \mathrm{m})$ natural seawater with a salinity of 35 , at $20^{\circ} \mathrm{C}$ under a light:dark cycle of $12: 12 \mathrm{~h}$ with a photon flux density of $110 \mu \mathrm{mol}$ photons $\mathrm{m}^{-2} \mathrm{~s}^{-1}$ provided by full spectrum cool white fluorescent tubes. Nutrients for autotrophic growth were added according to the GSe/2 medium recipe (Blackburn et al., 2001) and supplemented with $5 \mathrm{ml} \mathrm{l}^{-1}$ of soil extract, yielding in improved growth (Sweeney, 1951; Provasoli et al., 1957). Experimental cultures were kept in exponential growth by regular transfer to fresh media to avoid nutrient limitation.

\section{Experimental Set-Up}

Experimental incubations were carried out in duplicates under dilute batch culture conditions in $300 \mathrm{ml}$ sterile polystyrene Falcon ${ }^{\circledR}$ culture flasks with minimal headspace. Carbonate chemistry speciation was adjusted by the addition of calculated amounts of $\mathrm{HCl}, \mathrm{NaOH}$, and $\mathrm{NaHCO}_{3}$, resulting in a gradient of $\mathrm{pCO}_{2}$ from 445 to $1703 \mu$ atm (Table 1). Exponentially growing cultures were acclimated to the experimental conditions for three generations (5 days). Acclimated cultures were transferred to the experimental treatments to match a starting density of 100 cells $\mathrm{ml}^{-1}$ and were allowed to grow exponentially for 5 to 6 generations over the course of the experiment, corresponding to a maximal dissolved inorganic carbon $\left(C_{\mathrm{T}}\right)$ consumption of $3 \%$. The low biomass build up during the experiments ensured (1) nutrient replete conditions and (2) minor changes in the seawater carbonate chemistry due to biological activity (see also Riebesell et al., 2011). Samples for $C_{\mathrm{T}}$ and total alkalinity $\left(A_{\mathrm{T}}\right)$ were taken at the beginning and the end of the experimental incubations. Samples for cell density and ichthyotoxicity tests were taken at the end of the experiment.

\section{Carbonate Chemistry}

The carbonate system was monitored via triplicate $C_{\mathrm{T}}$ and $A_{\mathrm{T}}$ measurements applying the infrared detection method after Goyet and Snover (1993) with an Apollo SciTech DIC-Analyzer (Model AS-C3, Apollo SciTech, Newark, DE, United States) and the potentiometric titration method (Dickson et al., 2003), respectively. Data were corrected to repeated analyses of Certified Reference Materials (CRM, Scripps Institution of Oceanography, La Jolla, CA, United States) following the recommendations for ocean acidification research (Riebesell et al., 2011). Consecutive measurements of the CRM resulted in an average precision of $>99.8 \%$ for both $C_{\mathrm{T}}$ and $A_{\mathrm{T}}$. Carbonate system parameters, such as $\mathrm{pH}_{(\text {total scale) }}$, were calculated from temperature, salinity, $C_{\mathrm{T}}$ and $A_{\mathrm{T}}$ using CO2SYS (version 2.1 by E. Lewis and D. W. R. Wallace), with the stoichiometric equilibrium constants for carbonic acid given in Roy et al. (1993).

\section{Cell Density and Growth Rate}

Samples for cell density were measured in triplicate directly after sampling using a Coulter Multisizer ${ }^{\mathrm{TM}} 4$ (Beckman Coulter Life Sciences, Indianapolis, IN, United States) equipped with a $100 \mu \mathrm{m}$ aperture. Prior to each measurement, samples of $K$. veneficum were incubated at $4^{\circ} \mathrm{C}$ for $10 \mathrm{~min}$ in order to reduce cellular metabolism, avoiding undesired swimming motions during analysis. Equipment settings were calibrated using standard latex particles (Beckman Coulter Life Sciences) with a nominal size of $10 \mu \mathrm{m}$. The mean cell densities were used to calculate the growth rate, $\mu\left(\right.$ days $\left.^{-1}\right)$ as:

$$
\mu=\left(\ln c_{1}-\ln c_{0}\right) /\left(t_{1}-t_{0}\right),
$$

where $c_{0}$ and $c_{1}$ are the cell densities at the beginning $\left(t_{0}\right)$ and end of the incubation period $\left(t_{1}\right)$, expressed in days. Estimates of cell densities were associated with a random error of $<3 \%$, which was determined by repeated measurements of identical K. veneficum culture material $(n=10)$.

\section{Ichthyotoxicity Assessment Toxin Extraction}

The remaining $K$. veneficum cultures were pooled for each treatment (total of $400 \mathrm{ml}$ ) and centrifuged at $2000 \times g$ for $10 \mathrm{~min}$ (Sigma 3-16P). The supernatant was discarded 
TABLE 1 | Carbonate chemistry speciation ( $\pm 1 \mathrm{SD}$ ), averaged from the start and end values of the experimental incubations, with the corresponding growth rates ( $\mu$ ) of Karlodinium veneficum and the estimated LD 50 values, representing the lethal dose of $K$. veneficum cells for $50 \%$ of gill cell mortality.

\begin{tabular}{|c|c|c|c|c|c|c|}
\hline Treatment & \multicolumn{2}{|c|}{$\left(\mu \mathrm{mol} \mathrm{kg}^{-1}\right)$} & $\begin{array}{c}p \mathrm{CO}_{2} \\
\text { ( } \mu \text { atm) }\end{array}$ & $\begin{array}{c}\mathrm{pH} \\
\text { (total scale) }\end{array}$ & $\begin{array}{c}\mu \\
\text { (days }^{-1} \text { ) }\end{array}$ & $\begin{array}{c}\mathrm{LD}_{50} \\
\text { (cells } \mathrm{ml}^{-1} \text { ) }\end{array}$ \\
\hline 1 & $2113 \pm 7$ & $2389 \pm 59$ & $445 \pm 84$ & $8.03 \pm 0.08$ & 0.47 & 31,793 \\
\hline 2 & $2180 \pm 12$ & $2396 \pm 49$ & $603 \pm 91$ & $7.92 \pm 0.07$ & 0.46 & 38,458 \\
\hline 3 & $2273 \pm 22$ & $2383 \pm 53$ & $1112 \pm 170$ & $7.68 \pm 0.07$ & 0.45 & 45,722 \\
\hline 4 & $2320 \pm 27$ & $2386 \pm 60$ & $1515 \pm 274$ & $7.56 \pm 0.09$ & 0.43 & 145,594 \\
\hline 5 & $2342 \pm 34$ & $2388 \pm 29$ & $1703 \pm 83 x$ & $7.51 \pm 0.01$ & 0.42 & 108,757 \\
\hline
\end{tabular}

$T=20^{\circ} \mathrm{C}$, salinity $=35$, light intensity $=110 \mu \mathrm{mol}$ photons $\mathrm{m}^{-2} \mathrm{~s}^{-1}$.
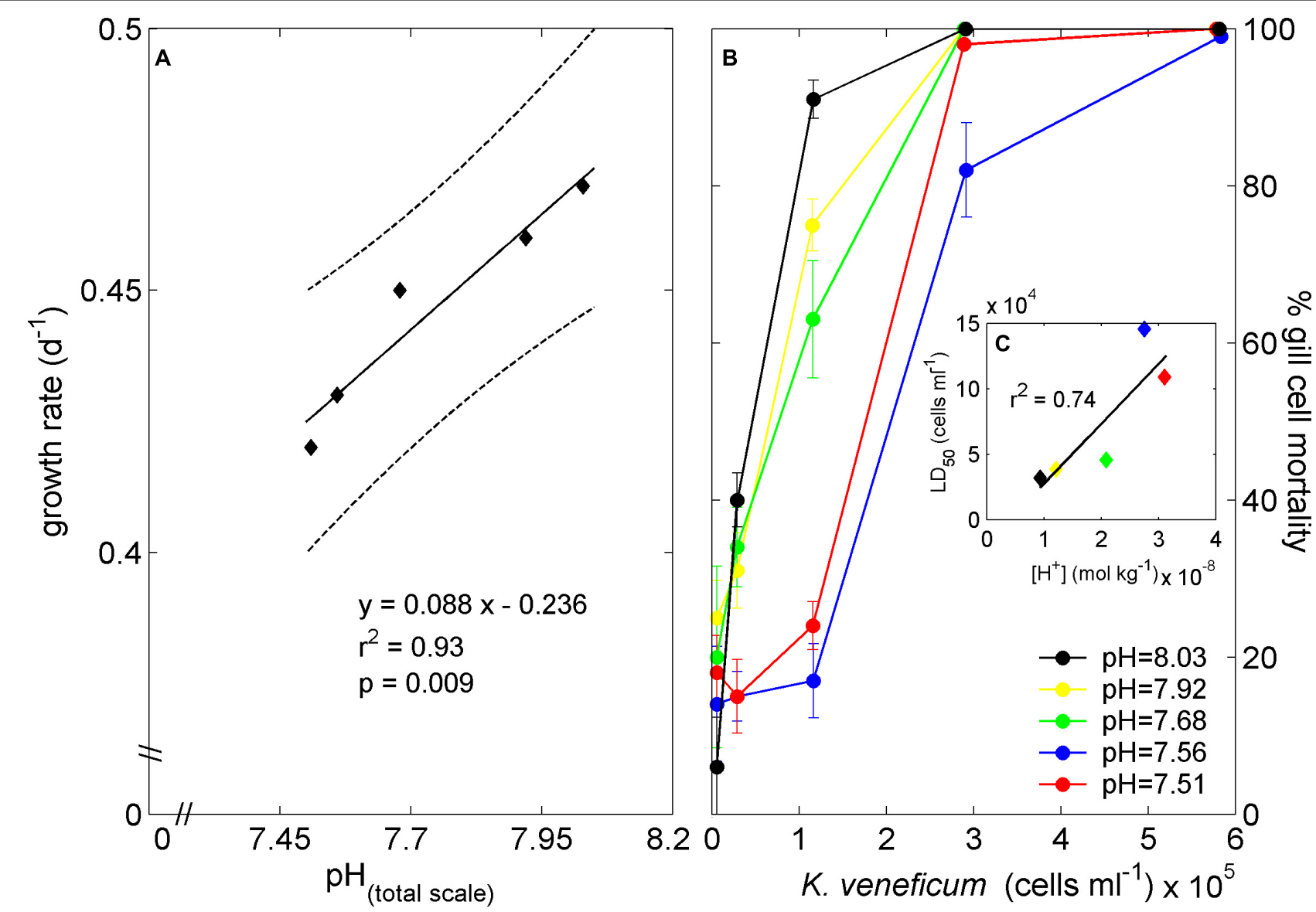

FIGURE 1 | Cellular growth rate response to changes in seawater $\mathrm{pH}(\mathbf{A})$ and gill cell mortality when exposed to dilution gradients of $K$. veneficum cell extracts with standard deviation derived from repeated fluorescent measurements (B). Black line in (A) represents linear regression fit with $95 \%$ prediction intervals (dashed line). $\mathrm{LD}_{50}$ values (cells $\mathrm{ml}^{-1}$ ) were estimated from idealized Michaelis-Menten-like fits to the treatment specific gill cell mortalities and plotted against seawater hydrogen concentration $(\mathbf{C})$. Linear regression fit in $(\mathbf{C})$ resulted in $\mathrm{LD}_{50}=4.59 \times 10^{12}\left[\mathrm{H}^{+}\right]-1.86 \times 10^{4}\left(r^{2}=0.74, p=0.062\right)$.

and cell pellets resuspended in methanol $(0.3-0.5 \mathrm{ml}$; based on cell densities of each treatment) to yield a constant final extract concentration equivalent to $5.7 \times 10^{6}$ cells $\mathrm{ml}^{-1}$. Resuspended pellets were sonicated with a probe type sonicator (Measuring and Scientific Equipment Ltd., London, United Kingdom) with tubes maintained in ice for $10 \mathrm{~min}$ at an amplitude of $7 \mu \mathrm{m}$ peak to peak, which describes the longitudinally expansion and contraction of the tip. Samples were kept on ice to counteract potential heating due to prolonged $(>1 \mathrm{~min})$ sonication. The applied settings were tested and resulted in a 99\% lysis of $K$. veneficum cells which was verified via Coulter Multisizer ${ }^{\mathrm{TM}} 4$ analyses. After sonication the sample was centrifuged at $1400 \times g$ for $10 \mathrm{~min}$, the resulting supernatant was collected and stored at $-20^{\circ} \mathrm{C}$ for a maximum of $24 \mathrm{~h}$ before testing the toxicity on gill cell lines. 


\section{Gill Cell Line Assay}

The fish gill cell line RTgill-W1 was maintained and used for the experiments following the protocol described by Dorantes-Aranda et al. (2011). Gill cells grown in L-15 medium (L1518, Sigma) were seeded into 96-well plates

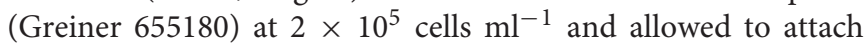
for $48 \mathrm{~h}$. Confluence of the adherent gill cell monolayer was confirmed by light microscopy, and L-15 medium was replaced with L-15/ex medium (Schirmer et al., 1997) $12 \mathrm{~h}$ before the experimental exposures. $K$. veneficum extracts were diluted to $0.1-10 \%$ in $\mathrm{L}-15 / \mathrm{ex}$ medium. The final methanol concentration for all experimental treatments, including the non-toxic control (L-15/ex), was $10 \%$. Immediately prior to exposures, the L-15/ex medium was discarded and $100 \mu \mathrm{L}$ of each treatment was added to quadruplicate wells, and plates were incubated for $2 \mathrm{~h}$ at experimental light conditions. After this period, individual plates were rinsed twice with $100 \mu \mathrm{L}$ phosphate buffer saline to subsequently receive $100 \mu \mathrm{L}$ of $5 \%$ resazurin in L-15/ex. Plates were incubated for a further $2 \mathrm{~h}$ in the dark. The gill cell metabolic reduction of resazurin to fluorescent resorufin was quantified using a microplate reader (Fluostar Optima, BMG Labtech), with excitation and emission wavelengths of 540 and $590 \mathrm{~nm}$, respectively. Fluorescence values were blank corrected (resazurin only, no gill cells) and results were expressed as percentage of mortality compared to the non-toxic control.

\section{RESULTS AND DISCUSSION}

The experimental protocol applied to alter the seawater carbonate chemistry mimics the process of ocean acidification and resulted in elevated total dissolved inorganic carbon concentrations at constant total alkalinity (Table 1). Growth rates of K. veneficum were positively correlated with seawater $\mathrm{pH}$ (Figure 1A), resulting in a maximum observed growth rate of 0.47 days $^{-1}$ at a $\mathrm{pH}$ of 8.03. Certain variables of the seawater carbonate system (i.e., $\mathrm{CO}_{2}, \mathrm{HCO}_{3}{ }^{-}, \mathrm{CO}_{3}{ }^{2-}$, and $\mathrm{H}^{+}$) are directly associated with cellular processes, such as photosynthesis, growth and enzyme reactions. An increase of aquatic $\mathrm{CO}_{2}$ and $\mathrm{HCO}_{3}{ }^{-}$ concentrations at constant $\mathrm{pH}$ results commonly in enhanced growth and photosynthetic rates (McMinn et al., 2014, 2017). On the other hand, increased $\mathrm{H}^{+}$concentrations can disturb cellular homeostasis of cytosol pH (Suffrian et al., 2011) with generally negative consequences for phytoplankton growth (McMinn et al., 2014; Müller et al., 2015). These two general mechanisms jointly result in an optimum growth curve response over extended $\mathrm{pH} / \mathrm{CO}_{2}$ gradients and have been demonstrated for coccolithophore and dinoflagellate species (e.g., McMinn et al., 2014; Müller et al., 2017). The fertilizing effect of $\mathrm{CO}_{2}$ on growth rates of the dinoflagellate Alexandrium catenella has been observed in laboratory experiments at $\mathrm{pH}$ levels between 8.7 and 8.1 (Mardones et al., 2017). A further $\mathrm{pH}$ reduction $(<8.1)$ had the adverse effect and resulted in reduced growth of $A$. catenella, similar to the here observed growth response of $K$. veneficum (Figure 1A). The linear decrease in growth rate of $K$. veneficum, when $\mathrm{pH}$ is reduced from 8.03 to 7.51 (Figure 1), indicates that the optimum $\mathrm{pH}$ condition is located at a $\mathrm{pH}$ of $\geq 8.03$. Indeed, autotrophic growth rates of $K$. veneficum have been reported with rates up to 0.53 days $^{-1}$ at ambient $\mathrm{pH}$ of $~ 8.2$ under similar temperature, salinity and light settings (Calbet et al., 2011).

Gill cell mortality was enhanced with exposure to increasing densities of $K$. veneficum in all tested $\mathrm{pH}$ treatments (Figure 1B), and reached mortality of $99 \%$ at densities $>5.7 \times 10^{5}$ cells $\mathrm{ml}^{-1}$. Idealized Michaelis-Menten-like kinetics were fitted to the treatment specific gill cell mortalities and the number of $K$. veneficum cells responsible for a 50\% lethal dose for gill cells $\left(\mathrm{LD}_{50}\right)$ indicated a positive linear trend with increasing seawater hydrogen concentrations $\left(r^{2}=0.74, p=0.062\right.$, Figure 1C). An increased toxin content and production may facilitate prey paralysation and ingestion (Sheng et al., 2007, 2010) and, as suggested by our results, can be partly related to seawater $\mathrm{pH}$. The altered toxicity of $K$. veneficum (Figure 1) with varying $\mathrm{pH}$ levels can theoretically be induced by higher cellular toxin content or by elevated toxin potency under elevated $\mathrm{pH}$. However, the applied gill cell protocol to measure the toxicity excludes the latter possibility because toxin effects were tested under identical $\mathrm{pH}$ conditions. Thus, the here observed mechanism of increased toxicity at elevated seawater $\mathrm{pH}$ represents elevated cellular karlotoxins content compared to low pH conditions. Fu et al. (2010) documented no change in Karlodinium toxicity (measured as saponin equivalent) within a $\mathrm{pH}$ range from 8.37 to 7.94 under nutrient replete culture conditions. This is in good agreement with our results that indicate no substantial change in toxicity between the 8.03 and the 7.92 treatments (Figure 1). Under phosphate limited growth, however, Fu et al. (2010) observed an increased toxicity with decreasing $\mathrm{pH}$ (from 8.37 to 7.94 ). Phosphate limitation reduces cellular division rates in phytoplankton to ensure accurate DNA syntheses while the biosynthesis of carbon and nitrogen rich compounds proceeds, leading to organic compound accumulations inside the cell (Müller et al., 2008; Li et al., 2016). This could explain the increased toxicity under phosphate limitation with increased $\mathrm{CO}_{2}$ availability for biosynthesis (Fu et al., 2010), while, at the same time, $\left[\mathrm{H}^{+}\right]$concentration were not high enough to induce a negative effect on the cellular metabolism and toxin production. However, it should be stressed that $K$. veneficum demonstrates a high inter-strain physiological plasticity (Place et al., 2012) which hampers an overall generalization of results derived from laboratory experiments testing a single strain.

Aquaculture ponds with extensive farming activities can experience highly elevated $p \mathrm{CO}_{2}$ values reaching concentrations $>10,000$ Matm (Ellis et al., 2017) and it certainly would be of interest to test the physiological performance and ichthyotoxicity of $K$. veneficum under these extreme conditions. The amplitudes of oscillating $\mathrm{pH}$ regimes in aquaculture ponds and coastal environments are projected to expand due to ocean acidification and the associated increasing Revelle factor (Schulz and Riebesell, 2013). In the coming years, it will be essential to monitor and register the seawater carbonate chemistry as a basic environmental and experimental parameter in line with 
temperature, salinity, and nutrient concentrations to improve our understanding of HAB bloom dynamics.

\section{DATA AVAILABILITY}

All datasets generated for this study are included in the manuscript and/or the supplementary files.

\section{AUTHOR CONTRIBUTIONS}

MM, JD-A, AS, and MB conceived, designed, and performed the experiments and analysis. MM analyzed the data and wrote the manuscript with essential contributions from all authors.

\section{REFERENCES}

Adolf, J. E., Bachvaroff, T. R., Deeds, J. R., and Place, A. R. (2015). Ichthyotoxic Karlodinium veneficum (Ballatine) J Larsen in the upper swan river estuary (Western Australia): ecological conditions leading to a fish kill. Harmful Algae 48, 83-93. doi: 10.1016/j.hal.2015.07.006

Blackburn, S. I., Bolch, C. J. S., Haskard, K. A., and Hallegraeff, G. M. (2001). Reproductive compatibility among four global populations of the toxic dinoflagellate Gymnodinium catenatum (Dinophyceae). Phycologia 40, 78-87. doi: 10.2216/i0031-8884-40-1-78.1

Calbet, A., Bertos, M., Fuentes-Grünewald, C., Alacid, E., Figueroa, R., Renom, B., et al. (2011). Intraspecific variability in Karlodinium veneficum: growth rates, mixotrophy, and lipid composition. Harmful Algae 10, 654-667. doi: 10.1016/j. hal.2011.05.001

Carstensen, J., Chierici, M., Gustafsson, B. G., and Gustafsson, E. (2018). Longterm and seasonal trends in estuarine and coastal carbonate systems. Gob. Biogeochem. Cycles 32, 497-513. doi: 10.1002/2017GB005781

Dickson, A. G., Afghan, J. D., and Anderson, G. C. (2003). Reference materials for oceanic CO2 analysis: a method for the certification of total alkalinity. Mar. Chem. 80, 185-197. doi: 10.1016/S0304-4203(02)00133-0

Dorantes-Aranda, J. J., Waite, T. D., Godrant, A., Rose, A. L., Tovar, C. D., Woods, G. M., et al. (2011). Novel application of a fish gill cell line assay to assess ichthyotoxicity of harmful marine microalgae. Harmful Algae 10, 366-373. doi: 10.1016/j.hal.2011.01.002

Dore, J. E., Lukas, R., Sadler, D. W., Church, M. J., and Karl, D. M. (2009). Physical and biogeochemical modulation of ocean acidification in the central North Pacific. Proc. Natl. Acad. Sci. U.S.A. 106, 12235-12240. doi: 10.1073/pnas. 0906044106

Duarte, C. M., Hendriks, I. E., Moore, T. S., Olsen, Y. S., Steckbauer, A., Ramajo, L., et al. (2013). Is ocean acidification an open-ocean syndrome? Understanding anthropogenic impacts on seawater pH. Estuaries Coasts 36, 221-236. doi: 10.1007/s12237-013-9594-3

Dutkiewicz, S., Morris, J. J., Follows, M. J., Scott, J., Levitan, O., Dyhrman, S. T., et al. (2015). Impact of ocean acidification on the structure of future phytoplankton communities. Nat. Clim. Chang. 5, 1002-1006. doi: 10.1038/ nclimate 2722

Ellis, R. P., Urbina, M. A., and Wilson, R. W. (2017). Lessons from two high $\mathrm{CO} 2$ worlds - future oceans and intensive aquaculture. Glob. Chang. Biol. 23, 2141-2148. doi: 10.1111/gcb.13515

Escobar-Morales, S., and Hernández-Becerril, D. U. (2015). Free-living marine planktonic unarmoured dinoflagellates from the Gulf of Mexico and the Mexican Pacific. Botanica Marina 58, 9-22. doi: 10.1515/bot-2014-0049

Feely, R. A., Sabine, C. L., Hernandez-Ayon, J. M., Ianson, D., and Hales, B. (2008). Evidence for upwelling of corrosive "Acidified". Water onto the continental shelf. Science 320, 1490-1492. doi: 10.1126/science.1155676

Fu, F. X., Place, A. R., Garcia, N. S., and Hutchins, D. A. (2010). CO2 and phosphate availability control the toxicity of the harmful bloom dinoflagellate

\section{FUNDING}

This work was funded by the "Conselho Nacional de Desenvolvimento Científico e Tecnológico Brasil (CNPq, Processo: 405585/2013-6)," the University of Tasmania providing a Visiting Fellowship to $\mathrm{MM}$ and the Federal University of Pernambuco (Edital Propesq Professor Visitante $n^{\circ}$.01/2017).

\section{ACKNOWLEDGMENTS}

We are grateful for all reviewers' suggestions and comments which significantly improved the manuscript.

Karlodinium veneficum. Aquat. Microb. Ecol. 59, 55-65. doi: 10.3354/ame 01396

Goyet, C., and Snover, A. K. (1993). High-accuracy measurements of total dissolved inorganic carbon in the ocean - comparison of alternate detection methods. Mar. Chem. 44, 235-242. doi: 10.1016/0304-4203(93)90205-3

Li, M., Shi, X., Guo, C., and Lin, S. (2016). Phosphorus deficiency inhibits cell division but not growth in the dinoflagellate Amphidinium carterae. Front. Microbiol. 7:826. doi: 10.3389/fmicb.2016.00826

Mardones, J. I., Müller, M. N., and Hallegraeff, G. M. (2017). Toxic dinoflagellate blooms of Alexandrium catenella in Chilean fjords: a resilient winner from climate change. ICES J. Mar. Sci. 74, 988-995. doi: 10.1093/icesjms/fsw164

McMinn, A., Müller, M. N., Martin, A., and Ryan, K. G. (2014). The response of Antarctic sea ice algae to changes in $\mathrm{pH}$ and CO2. PLoS One 9:e86984. doi: 10.1371/journal.pone.0086984

McMinn, A., Müller, M. N., Martin, A., Ugalde, S. C., Lee, S., Castrisios, K., et al. (2017). Effects of CO2 concentrations on a late summer surface sea ice community. Mar. Biol. 164:87. doi: 10.1007/s00227-017-3102-4

Melzner, F., Thomsen, J., Koeve, W., Oschlies, A., Gutowska, M. A., Bange, H. W., et al. (2013). Future ocean acidification will be amplified by hypoxia in coastal habitats. Mar. Biol. 160, 1875-1888. doi: 10.1007/s00227-012-1954-1

Mooney, B. D., Hallegraeff, G. M., and Place, A. R. (2010). Ichthyotoxicity of four species of gymnodinioid dinoflagellates (Kareniaceae, Dinophyta) and purified karlotoxins to larval sheepshead minnow. Harmful Algae 9, 557-562. doi: 10.1016/j.hal.2010.04.005

Müller, M. N., Antia, A. N., and LaRoche, J. (2008). Influence of cell cycle phase on calcification in the coccolithophore Emiliania huxleyi. Limnol. Oceanogr. 53, 506-512. doi: 10.4319/lo.2008.53.2.0506

Müller, M. N., Trull, T. W., and Hallegraeff, G. M. (2015). Differing responses of three Southern Ocean Emiliania huxleyi ecotypes to changing seawater carbonate chemistry. Mar. Ecol. Progress Ser. 531, 81-90. doi: 10.3354/ meps11309

Müller, M. N., Trull, T. W., and Hallegraeff, G. M. (2017). Differing responses of three Southern Ocean Emiliania huxleyi ecotypes to changing seawater carbonate chemistry. ISME J. 11, 1777-1787. doi: 10.1038/ismej.2017.53

Place, A. R., Bowers, H. A., Bachvaroff, T. R., Adolf, J. E., Deeds, J. R., and Sheng, J. (2012). Karlodinium veneficum - The little dinoflagellate with a big bite. Harmful Algae 14, 179-195. doi: 10.1016/j.hal.2011.10.021

Provasoli, L., McLaughlin, J. J., and Droop, M. R. (1957). The development of artificial media for marine algae. Arch. Mikrobiol. 25, 392-428. doi: 10.1007/ BF00446694

Riebesell, U., Fabry, V. J., Hansson, L., and Gattuso, J.-P. (eds) (2011). Guide to Best Practices for Ocean Acidification Research and Data Reporting. Luxembourg: Publications Office of the European Union, 258. doi: 10.2777/66906

Roy, R. N., Roy, L. N., Vogel, K. M., Porter-Moore, C., Pearson, T., Good, C. E., et al. (1993). The dissociation constants of carbonic acid in seawater at salinities 5 to 45 and temperatures 0 to $45^{\circ}$ C. Mar. Chem. 44, 249-267. doi: $10.1016 / 0304$ 4203(93)90207-5 
Schirmer, K., Chan, A. G. J., Greenberg, B. M., Dixon, D. G., and Bols, N. C. (1997). Methodology for demonstrating and measuring the photocytotoxicity of fluoranthene to fish cells in culture. Toxicol. Vitro 11, 107-119. doi: 10.1016/ S0887-2333(97)00002-7

Schulz, K. G., and Riebesell, U. (2013). Diurnal changes in seawater carbonate chemistry speciation at increasing atmospheric carbon dioxide. Mar. Biol. 160, 1889-1899. doi: 10.1007/s00227-012-1965-y

Sheng, J., Malkiel, E., Katz, J., Adolf, J., Belas, R., and Place, A. R. (2007). Digital holographic microscopy reveals prey-induced changes in swimming behavior of predatory dinoflagellates. Proc. Natl. Acad. Sci. U.S.A. 104, 17512-17517. doi: 10.1073/pnas.0704658104

Sheng, J., Malkiel, E., Katz, J., Adolf, J., and Place, A. R. (2010). A dinoflagellate exploits toxins to immobilize prey prior to ingestion. Proc. Natl. Acad. Sci. U.S.A. 107, 2082-2087. doi: 10.1073/pnas.0912254107

Suffrian, K., Schulz, K. G., Gutowska, M. A., Riebesell, U., and Bleich, M. (2011). Cellular pH measurements in Emiliania huxleyi reveal pronounced membrane proton permeability. New Phytologist 190, 595-608. doi: 10.1111/j.1469-8137. 2010.03633.x
Sweeney, B. M. (1951). Culture of the Dinoflagellate Gymnodinium with soil extract. Am. J. Bot. 38, 669-677. doi: 10.2307/2437913

Torres, R., Pantoja, S., Harada, N., González, H. E., Daneri, G., Frangopulos, M., et al. (2011). Air-sea CO2 fluxes along the coast of Chile: from CO2 outgassing in central northern upwelling waters to $\mathrm{CO} 2$ uptake in southern Patagonian fjords. J. Geophys. Res. 116, 1-17. doi: 10.1029/2010JC006344

Conflict of Interest Statement: The authors declare that the research was conducted in the absence of any commercial or financial relationships that could be construed as a potential conflict of interest.

Copyright (ㄷ) 2019 Müller, Dorantes-Aranda, Seger, Botana, Brandini and Hallegraeff. This is an open-access article distributed under the terms of the Creative Commons Attribution License (CC BY). The use, distribution or reproduction in other forums is permitted, provided the original author(s) and the copyright owner(s) are credited and that the original publication in this journal is cited, in accordance with accepted academic practice. No use, distribution or reproduction is permitted which does not comply with these terms. 